\title{
Sistem penunjang keputusan penetapan siswa inklusi kesulitan belajar di sekolah dasar
}

\author{
Novia Lestari ${ }^{1}$, Lucky Lhaura Van FC $^{2}$ \\ ${ }^{1}$ Program Studi Manajemen Informatika Universitas Mahaputra Muhammad Yamin - Solok \\ Jl. Raya Kotobaru No. 7 Kab. Solok \\ ${ }^{2}$ Program Studi Teknik Informatika Universitas Lancang Kuning \\ Jl. Yos Sudarso KM. 8 Rumbai, Pekanbaru, Riau, telp. 08117532015 \\ Email : ${ }^{1}$ Novia_Lestarii@ rocketmail.com, ${ }^{2}$ Lucky@ unilak.ac.id
}

\begin{abstract}
Abstrak
Pendidikan merupakan hak semua warganegara, tak terkecuali bagi warganegara yang memiliki kelainan fisik, emosional, mental, intelektual dan/atau sosial, yang berhak memperoleh pendidikan khusus. Salah satu implementasinya adalah berupa kebijakan dari dinas pendidikan kabupaten/kota yang menyarankan sekolah reguler siap sedia memberikan program inklusi jika memiliki siswa Inklusi atau berkebutuhan khusus, salah satunya adalah siswa inklusi kesulitan belajar. Permasalahan yang sering dihadapi dalam penetapan siswa inklusi adalah saat menyelenggarakan proses belajar mengajar, kepala sekolah bersama dengan guru-guru harus memilih dan menetapkan peserta didik yang patut mendapakan pendidikan inklusi sesuai dengan kriteria yang telah ditetapkan. Saat ini penilaian dari setiap kriteria belum menggunakan suatu metode keputusan, sehingga penilaian antar peserta masih menggunakan prediksi atau perkiraan yang dapat menimbulkan penilaian bersifat subyektif. Dampak lebih lanjut dari permasalahan tersebut yaitu menimbulkan kurang tepatnya pemilihan siswa inklusi kesulitan. Dengan perkembangan teknologi informasi yang mencakup segala bidang, perlu dirancang sebuah sistem yang dapat membantu dalam penetapan siswa inklusi kesulitan belajar, agar dapat membantu mempermudah pihak sekolah dalam menyeleksi dan menetapkan siswa inklusi kesulitan belajar, sehingga hasil yang diinginkan tepat sasaran dan sesuai dengan kriteria yang telah ditetapkan. Hal tersebut dapat terbantu dengan sistem pendukung keputusan penetapan siswa inklusi kesulitan belajar menggunakan metode Analitycal Hierarcy Process (AHP) yang mampu membantu memecahkan persoalan yang kompleks menjadi lebih sederhana dan mempercepat proses pengambilan keputusan.
\end{abstract}

Kata kunci : Sistem Penunjang Keputusan, Siswa Inklusi, Kesulitan Belajar

\begin{abstract}
Education is the rightful authority of all citizens, not to the exception of citizens with physical, emotional, mental, intellectual and / or social impairments, who are entitled to special education. One of the implementation is in the form of policy from the district / municipality education office that recommends regular schools are ready to provide inclusion program if they have Inclusive or special needs students, one of them is student of learning inclusion difficulties. The problem often encountered in establishing inclusive students is when conducting the teaching and learning process, the principal along with the teachers should select and assign learners who deserve inclusion education in accordance with predetermined criteria. Where the assessment of each criterion has not yet used a decision method, so assessment among participants still uses predictions or estimates that may lead to subjective judgments. So as to elicit precisely the selection of student inclusion of learning difficulties. With the development of information technology covering all fields, it is necessary to design a system that can assist in determining student inclusion of learning difficulties, in order to help facilitate the school in selecting and establishing student inclusion of learning difficulties, so that the desired results on target and in accordance with the criteria that have been set.
\end{abstract}

Keywords: Decision Support Systems, Inclusion Students, Learning Difficulties 


\section{Pendahuluan}

\subsection{Latar Belakang}

Dalam Undang Undang Dasar 1945 pasal 31 ayat 1 [1] dan Undang-Undang Nomor 20 tahun 2003 tentang Sistem Pendidikan Nasional [2], dinyatakan bahwa setiap warganegara mempunyai hak yang sama untuk memperoleh pendidikan, tak terkecuali bagi warganegara yang memiliki kelainan fisik, emosional, mental, intelektual dan/atau social, yang berhak memperoleh pendidikan khusus. Hal ini menunjukkan bahwa anak yang memiliki kelainan dan/atau memiliki potensi kecerdasan dan bakat istimewa berhak pula memperoleh kesempatan yang sama dengan anak lainnya (anak normal) dalam memperoleh pendidikan. Hal tersebut juga didukung melalui kebijakan yang terkait kurikulum yang terus disempurnakan, hingga pelaksanaan program pendidikan yang berbasis wacana pendidikan untuk semua atau yang disebut pendidikan inklusi. Dimana Dinas Pendidikan menyarankan sekolah reguler siap sedia memberikan program inklusi jika memiliki siswa Inklusi atau berkebutuhan khusus.

Siswa inklusi adalah anak berkebutuhan khusus yang ikut serta belajar di kelas umum atau biasa dengan anak-anak lainnya, seperti anak yang memiliki kesulitan melihat atau mendengar, tidak dapat berjalan, autis, atau lebih lamban dalam belajar [3]. Pengelompokan anak berkebutuhan khusus dan jenis pelayanannya, sesuai dengan Program Direktorat Pembinaan Sekolah Luar Biasa Tahun 2006 [4] dan Pembinaan Direktorat Jenderal Manajemen Pendidikan Dasar Dan Menengah Departemen Pendidikan Nasional Pendidikan berupa tuna netra, tuna rungu, tuna grahita: (a.l. Down Syndrome), tuna grahita ringan $(\mathrm{IQ}=50-70)$, tuna grahita sedang (IQ = 25-50), tuna grahita berat (IQ 125 ), kesulitan belajar (a.l. Hyperaktif, ADD/ADHD, Dyslexia/Baca, Dysgraphia/Tulis, Dyscalculia/Hitung, Dysphasia/Bicara, Dyspraxia/ Motorik), lambat belajar ( IQ = 70-90), autis, korban penyalahgunaan narkoba, dan indigo.

Permasalahan yang sering dihadapi dalam penetapan siswa inklusi adalah saat menyelenggarakan proses belajar mengajar, kepala sekolah bersama dengan guru-guru harus memilih dan menetapkan peserta didik yang patut mendapatkan pendidikan inklusi sesuai dengan kriteria yang telah ditetapkan Direktorat Pembinaan Sekolah Luar Biasa tersebut. Terkadang dalam proses menyeleksi peserta didik sering terjadi kekeliruan dan tidak tepat sasaran sehingga terjadi permasalahan ketika menetapkan siswa yang tergolong siswa inklusi saat pemeriksaan dari Dinas Pendidikan ke sekolah. Dan penilaian dari setiap kriteria belum menggunakan suatu metode keputusan, sehingga penilaian antar peserta masih menggunakan prediksi atau perkiraan yang dapat menimbulkan penilaian bersifat subyektif. Sehingga menimbulkan kurang tepatnya pemilihan siswa inklusi kesulitan belajar ini.

Seiring perkembangan teknologi informasi, masalah pemilihan siswa inklusi supaya tepat sasaran sesuai kriteria yang ditentukan oleh pemerintah melalui Dinas Pendidikan dapat diatasi, salah satunya adalah dengan pemanfaatan sistem penunjang keputusan dengan metode Analytical Hierarcy Process (AHP) untuk penetapan siswa inklusi kesulitan belajar. Dimana dengan sistem ini, dapat membantu mempermudah pihak sekolah dalam menyeleksi dan menetapkan siswa inklusi kesulitan belajar, sehingga hasil yang diinginkan tepat sasaran dan sesuai dengan kriteria yang telah ditetapkan. Karena Dalam penerapannya, SPK memanfaatkan data dan model matematis untuk menyelesaikan masalah-masalah yang tidak terstruktur, mulai dari mengidentifikasi masalah, memilih data yang relevan, menentukan pendekatan yang digunakan dalam proses pengambilan keputusan, sampai mengevaluasi pemilihan alternative [5]. Hal ini dapat dilihat pada implementasi sistem penunjang keputusan dalam berbagai bidang, salah satunya dalam pemberian bantuan kepada masyarakat desa, dimana dengan sistem pendukung keputusan menggunakan metode Analytical Hierarcy Process (AHP), dapat ditentukan kriteria keluarga miskin di satu desa, sesuai dengan aturan dan kriteria yang telah ditetapkan pemerintah, guna mencegah salah sasaran dan kecurangan yang dilakukan oleh pihak tertentu [6]. 
Analytical Hierarchy Process (AHP) merupakan sebuah hirarki fungsional dengan input utamanya persepsi manusia. Analytical Herarchy Process digunakan dengan tujuan untuk menyusun prioritas dari berbagai alternatif dalam kelompok yang diatur menjadi suatu bentuk hirarki [7]. Analytical hierarchy process (AHP) merupakan salah satu metode untuk membantu menyusun prioritas dari berbagai pilihan dengan menggunakan beberapa kriteria (multi criteria) [8]. Metode ini adalah sebuah kerangka untuk mengambil keputusan dengan efektif atas persoalan yang kompleks dengan menyederhanakan dan mempercepat proses pengambilan keputusan dengan memecahkan persoalan tersebut kedalam bagian-bagiannya, menata bagian atau variabel ini dalam suatu susunan hirarki, member nilai numerik pada pertimbangan subjektif tentang pentingnya tiap variabel dan mensintesis berbagai pertimbangan ini untuk menetapkan variabel yang mana yang memiliki prioritas paling tinggi dan bertindak untuk mempengaruhi hasil pada situasi tersebut [9].

\section{Metode Penelitian}

Dalam penelitian ini metode penelitian yang digunakan adalah Metode Penelitian dan Pengembangan (Research and Development/R\&D), yaitu mengembangkan suatu produk baru atau menyempurnakan produk yang telah ada, yang dapat dipertanggungjawabkan dimana produk tersebut tidak selalu berbentuk benda atau perangkat keras (hardware), seperti buku, modul, alat bantu pembelajaran di kelas atau di laboratorium, tetapi bisa juga perangkat lunak (software), seperti Sistem penunjang keputusan untuk penetapan siswa inklusi kesulitan belajar ini.

Langkah-langkah dalam penelitian SPK menggunakan metode AHP secara umum untuk pemecahan suatu masalah adalah sebagai berikut :[10]

1. Mendefinisikan masalah dan menentukan solusi yang diinginkan.

2. Membuat struktur hierarki yang diawali dengan tujuan umum, dilanjutkan dengan kriteriakriteria dan alternatif- alternatif pilihan.

3. Membuat matrik perbandingan berpasangan yang menggambarkan kontribusi relatif atau pengaruh setiap elemen terhadap tujuan atau kriteria yang setingkat di atasnya. Perbandingan dilakukan berdasarkan pilihan atau judgement dari pembuat keputusan dengan menilai tingkat kepentingan suatu elemen dibandingkan elemen lainnya.

4. Menormalkan data yaitu dengan membagi nilai dari setiap elemen di dalam matrik yang berpasangan dengan nilai total dari setiap kolom

5. Menghitung nilai bobot setiap elemen (eigen vector) dengan rumus :

$$
£ \text { maks }=£ \text { kriteria } 1+\ldots \ldots+£ \text { kriteria } n
$$

\begin{tabular}{lll}
\multirow{2}{*}{ Dimana } & & $n$ \\
& £maks & $=$ eigen vector \\
$£$ kriteria & $=$ nilai bobot kriteria \\
$\mathrm{n}$ & $=$ jumlah kriteria
\end{tabular}

kemudian menguji konsistensinya (CI) dengan rumus:

$$
\begin{array}{ll}
C I=(£ \text { maks }-n) / n \\
\text { Dimana : } \quad \mathrm{CI}=\text { Consistency Index } \\
& \mathrm{n}=\text { jumlah kriteria } \\
& £ \text { maks }=\text { Eigen vector maksimun }
\end{array}
$$

jika tidak konsisten maka pengambilan data (preferensi) perlu diulangi.

6. Mengulangi langkah 3, 4 dan 5 untuk seluruh tingkat hirarki.

7. Menghitung eigen vector dari setiap matriks perbandingan berpasangan.

8. Menguji konsistensi hirarki. 
$C R=C I / \mathrm{R}$

Dimana $\quad \mathrm{CR}=$ Consistency Ratio

$\mathrm{CI}=$ Consistency Index

$\mathrm{RI} \quad=$ Indeks Random Consistency

RI di dapat dari tabel nilai, Nilai RI dapat kita lihat pada Tabel 1 berikut :

Tabel 1. Tabel Nilai RI

\begin{tabular}{|c|c|c|c|c|c|c|c|c|c|c|}
\hline $\mathrm{n}$ & 1 & 2 & 3 & 4 & 5 & 6 & 7 & 8 & 9 & 10 \\
\hline $\mathrm{RI}$ & 0 & 0 & $\begin{array}{c}5, \\
8\end{array}$ & $\begin{array}{c}0, \\
9\end{array}$ & $\begin{array}{c}1,1 \\
2\end{array}$ & $\begin{array}{c}1,2 \\
4\end{array}$ & $\begin{array}{c}1,3 \\
2\end{array}$ & $\begin{array}{c}1,4 \\
1\end{array}$ & $\begin{array}{c}1, \\
45\end{array}$ & $\begin{array}{c}1,4 \\
9\end{array}$ \\
\hline
\end{tabular}

Jika tidak memenuhi dengan $\mathrm{CR}<0,100$ maka penilaian harus diulangi kembali.

9. Membuat matrik perbandingan berpasangan yang menggambarkan kontribusi relative dari masing-masing alternative terhadap kriteria-kriteria.

10. Membuat overall composit matrix (nilai perbandingan keseluruhan alternative terhadap kriteria)

\section{Hasil dan Pembahasan}

\subsection{Analisa Sistem Yang Sedang Berjalan}

1. Identification dan selection

Analisa sistem ini bertujuan untuk merancang sistem yang baru, merancang perubahan-perubahan dalam pengambilan keputusan serta mengetahui bagaimana sistem pengolahannya dan mengetahui masalah yang ditemukan dalam proses pengambilan keputusan. Analisa sistem merupakan penelusuran dari sistem yang sedang berjalan, sehingga memudahkan analsis dalam pendefenisian permasalahan yang timbul dalam instansi/lembaga untuk membuat sistem baru.

Sistem lama yang ada pada SDN 01 Tanjung Haro Sikabu-kabu masih secara manual untuk menentukan siswa yang termasuk siswa inklusi atau berkebuthan khusus tersebut, sehingga sering terjadi kekeliruan dan kesalahan yang tidak di inginkan. Untuk itu perlu dibuat sistem penunjang keputusan agar sistem kerja lebih akurat, efisien dan efektif yang dapat mengurangi kesalahan yang terjadi. Untuk lebih jelasnya mengenai aliran sistem yang sedang berjalan di SDN 01 Tanjung Haro Sikabu-kabu ini dapat kita lihat pada gambar 2 dimana gambaran aliran data dan informasi yang disajikan dalam ASI lama menggunakan beberapa simbol-simbol untuk mewakili beberapa proses dan arus data yang terjadi sebenarnya. Adapun aliran sistem lama tersebut adalah sebagai berikut : 


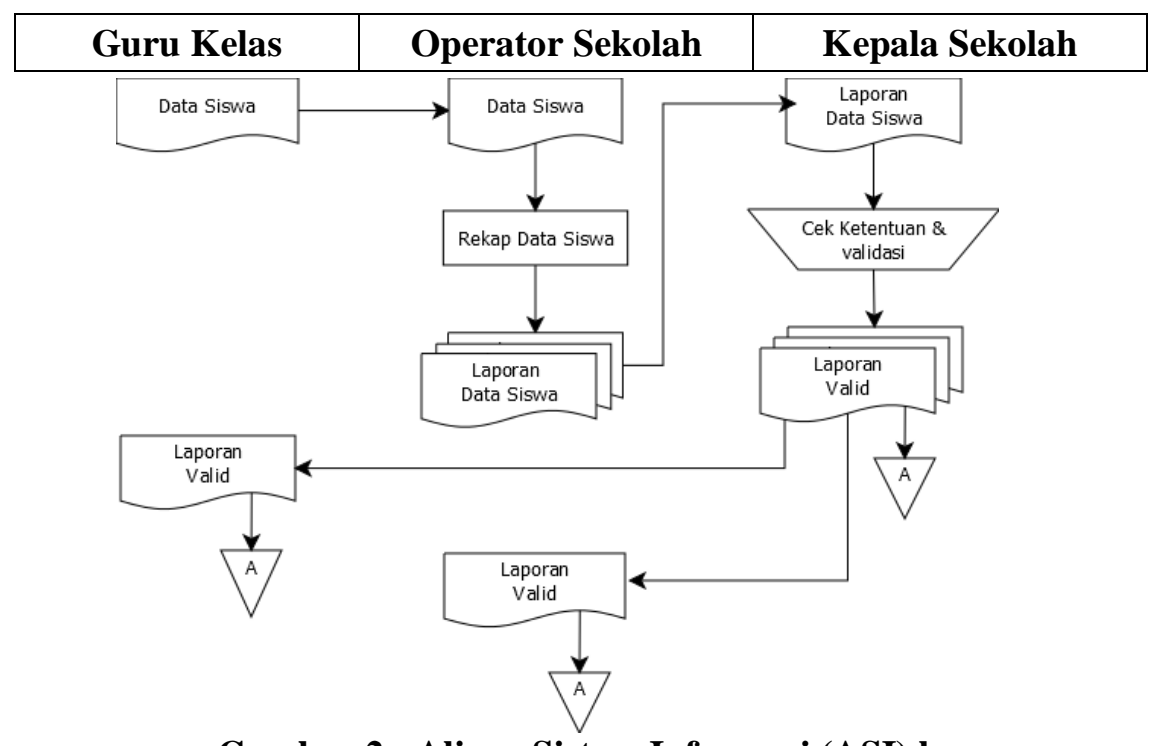

Gambar 2 : Aliran Sistem Informasi (ASI) lama

Gambar 2 di atas dapat dijelaskan mengenai Aliran Sistem Informasi lama tentang pemilihan Siswa Inklusi dilakukan secara manual yang hanya ditentukan oleh kepala sekolah dan begitu juga dengan pengarsipannya. Sistem ini dimulai dari guru kelas yang memberikan data siswa yang dipilih nya secara manual dikelasnya masing-masing ke operator sekolah, lalu data siswa tersebut di input/ direkap yang selanjutnya menghasilkan laporan data siswa. Selanjutnya laporan data siswa yang telah dicetak diserahkan kepada kepala sekolah , kemudian kepala sekolah untuk dicek kembali apa data tersebut sudah benar dan sesuai dengan ketentuan tertentu, setelah laporan valid, dan kemudian kemudian laporan valid tersebut di berikan ke guru kelas dan operator sekolah sebagai arsip.

Berdasarkan analisa yang telah dilakukan terlihat bahwa dalam sistem yang lama terdapat beberapa kelemahan yaitu :

1) Menghasilkan laporan atau informasi memerlukan waktu yang lama karena pemprosesan data dilakukan secara manual.

2) Sering terjadi kesalahan-kesalahan dalam pengambilan keputusan tentang pemilihan siswa inkusi kesulitan belajar.

3) Hasil tidak sesuai dengan yang diinginkan karena sering terjadi tidak tepat sasaran terhadap siswa inklusi yang benar-benar tergolong siswa inklusi kesulitan belajar.

\section{Initiation and Planning (Inisialisasi dan Perencanaan)}

Untuk mengatasi permasalahan yang timbul dalam menyeleksi Siswa Inklusi di SDN 01 Tanjung Haro Sikabu-kabu, maka dilakukan suatu bentuk pengembangan sistem pengolahan data seleksi siswa inklusi didukung oleh Sistem Pendukung Keputusan (SPK) dengan alat bantu komputer, sehingga hasil lebih akurat, tepat dan sesuai dengan yang inginkan. Sistem pendukung keputusan inii akan dipakai kreteria yang didasarkan pada syarat-syarat yang telah ditentukan.

Adapun kriteria yang digunakan yaitu :

a) Kriteria Kemampuan membaca

1) Nilai $<=60$ termasuk kategori kurang dengan bobot 1

2) Nilai $<75$ dan $>60$ termasuk kategori sedang dengan bobot 2

3) Nilai $<=100$ termasuk kategori baik dengan bobot 3 
b) Kriteria Kemampuan berhitung

1) Nilai $<=60$ termasuk kategori kurang dengan bobot 1

2) Nilai $<75$ dan $>60$ termasuk kategori sedang dengan bobot 2

3) Nilai $<=100$ termasuk kategori baik dengan bobot 3

c) Kirteria Kemampuan menulis huruf atau angka

1) Nilai $<=60$ termasuk kategori kurang dengan bobot 1

2) Nilai $<75$ dan $>60$ termasuk kategori sedang dengan bobot 2

3) Nilai $<=100$ termasuk kategori baik dengan bobot 3

\section{Analyze (Analisa)}

Keunggulan dari Sistem Pendukung Keputusan (SPK) ini dibanding dengan sistem yang sedang diterapkan adalah mengurangi kesalahan dari ketidak akuratannya data tentang siswa inklusi yang diseleksi, yang biasany pemelihan siswa inklusi hanya ditunjuk-tunjuk saja oleh pihak sekolah. Dengan adanya SPK ini maka siswa yang dipilih dan diseleksi benar-benar yang tergolong siswa inklusi kesulitan belajar.

Perhitungan penetapan siswa inklusi menggunakan metode AHP adalah sebagai berikut :

1. Membuat matrik Pairwise Comparison Masing- masing Kriteria

a. Kriteria kemampuan membaca 4 kali lebih penting dari kemampuan berhitung, dan 1,5 kali lebih penting dari kemampuan menulis.

b. Kriteria kemampuan berhitung 3 kali lebih penting dari kemampuan menulis.

Tabel 2. Perbandingan dan normalisasi

\begin{tabular}{|l|l|l|l|}
\hline Kriteria & KR1 & KR2 & KR3 \\
\hline KR1 & 1 & 1,5 & 4 \\
\hline KR2 & $1 / 1,5$ & 1 & 3 \\
\hline KR3 & $1 / 4$ & $1 / 3$ & 1 \\
\hline
\end{tabular}

Tabel 3. Pencarian Jumlah Kolom

\begin{tabular}{|l|l|l|l|l|}
\hline Kriteria & KR1 & KR2 & KR3 & Priority vector \\
\hline KR1 & 1 & 1,5 & 4 & 0.513 \\
\hline KR2 & $1 / 1,5=0.7$ & 1 & 3 & 0.362 \\
\hline KR3 & $1 / 4=0.25$ & $1 / 3=0.33$ & 1 & 0.123 \\
\hline Jml Kolom & 1.95 & 2,83 & 8.00 & \\
\hline
\end{tabular}

2. Menghitung Rasio Konsistensi

menentukan nilai Eigen Maksimum ( $\lambda$ maks )

$\lambda$ maks $=(1.95 * 0.513)+(2.83 * 0.362)+(8.00 * 0.123)$

$$
=3.0
$$

Menentukan Indeks Konsistensi (CI) :

$$
\begin{aligned}
\mathrm{CI} & =(\lambda \text { maks }-\mathrm{n}) / \mathrm{n}-1 \\
& =(3.0-3) / 3-1=0
\end{aligned}
$$

Menghitung Rasio Konsistensi (CR) :

$\mathrm{CR}=\mathrm{CI} / \mathrm{RI}$

$=0 / 0.58=0 \%$

Karena nilai CR $<0.1$ maka perhitungan dapat diterima (konsisten) 
3. Membuat matrik Pairwise Comparison masing- masing alternative

Tabel 4. Priority Vector Alternative Terhadap Kriteria 1

\begin{tabular}{|l|l|l|l|l|}
\hline Kriteria1 & siswa1 & siswa2 & siswa3 & Priority vector \\
\hline siswa 1 & 1 & 4 & 3 & 0.623 \\
\hline siswa 2 & 0.25 & 1 & 0.5 & 0.333 \\
\hline siswa 3 & 0.33 & 2 & 1 & 0.233 \\
\hline Jml Kolom & 1.58 & 7 & 4.5 & \\
\hline
\end{tabular}

Tabel 5. Priority Vector Alternative Terhadap Kriteria 2

\begin{tabular}{|l|l|l|l|l|}
\hline Kriteria2 & siswa1 & siswa2 & siswa3 & Priority vector \\
\hline siswa 1 & 1 & 0.5 & 2 & 0.364 \\
\hline siswa 2 & 2 & 1 & 3 & 0.333 \\
\hline siswa 3 & 0.5 & 0.33 & 1 & 0.333 \\
\hline Jml Kolom & 3.2 & 1.83 & 6 & \\
\hline
\end{tabular}

Tabel 6. Priority Vector Alternative Terhadap Kriteria 3

\begin{tabular}{|l|l|l|l|l|}
\hline Kriteria3 & siswa1 & siswa2 & siswa3 & Priority vector \\
\hline siswa 1 & 1 & 0.33 & 2 & 0.333 \\
\hline siswa 2 & 3.03 & 1 & 3 & 0.999 \\
\hline siswa 3 & 0.5 & 0.33 & 1 & 0.333 \\
\hline Jml Kolom & 4.53 & 1.66 & 6 & \\
\hline
\end{tabular}

Tabel 7. Overall Composit Matrix

\begin{tabular}{|l|l|l|l|l|}
\hline \multicolumn{1}{|c|}{ Kriteria } & $\begin{array}{c}\text { Priority Vector } \\
\text { Kriteria }\end{array}$ & siswa1 & siswa2 & siswa3 \\
\hline KR1 & 0.513 & 0.623 & 0.333 & 0.233 \\
\hline KR2 & 0.362 & 0.364 & 0.333 & 0.333 \\
\hline KR3 & 0.123 & 0.333 & 0.999 & 0.333 \\
\hline $\begin{array}{l}\text { Composit } \\
\text { Weight }\end{array}$ & & 0,493 & 0.415 & 0.271 \\
\hline
\end{tabular}

Dari nilai composit weight pada tabel 7 di atas, dapat dilihat bahwa siswa1 memiliki nilai tertinggi yang berarti bahwa siswal diprioritaskan sebagai siswa inklusi berdasarkan penilaian dengan metode AHP sesuai dengan kriteria-kriteria yang telah ditentukan.

\section{Design Logika (Prencanaan secara logika)}

Untuk gambaran tentang aliran sistem yang diusulkan dapat dilihat dari Aliran Sistem Informasi (ASI) baru dari hasil pengembangan sistem yang dilakukan. Adapun skema dari ASI baru tersebut dapat kita pada gambar 3 berikut ini : 


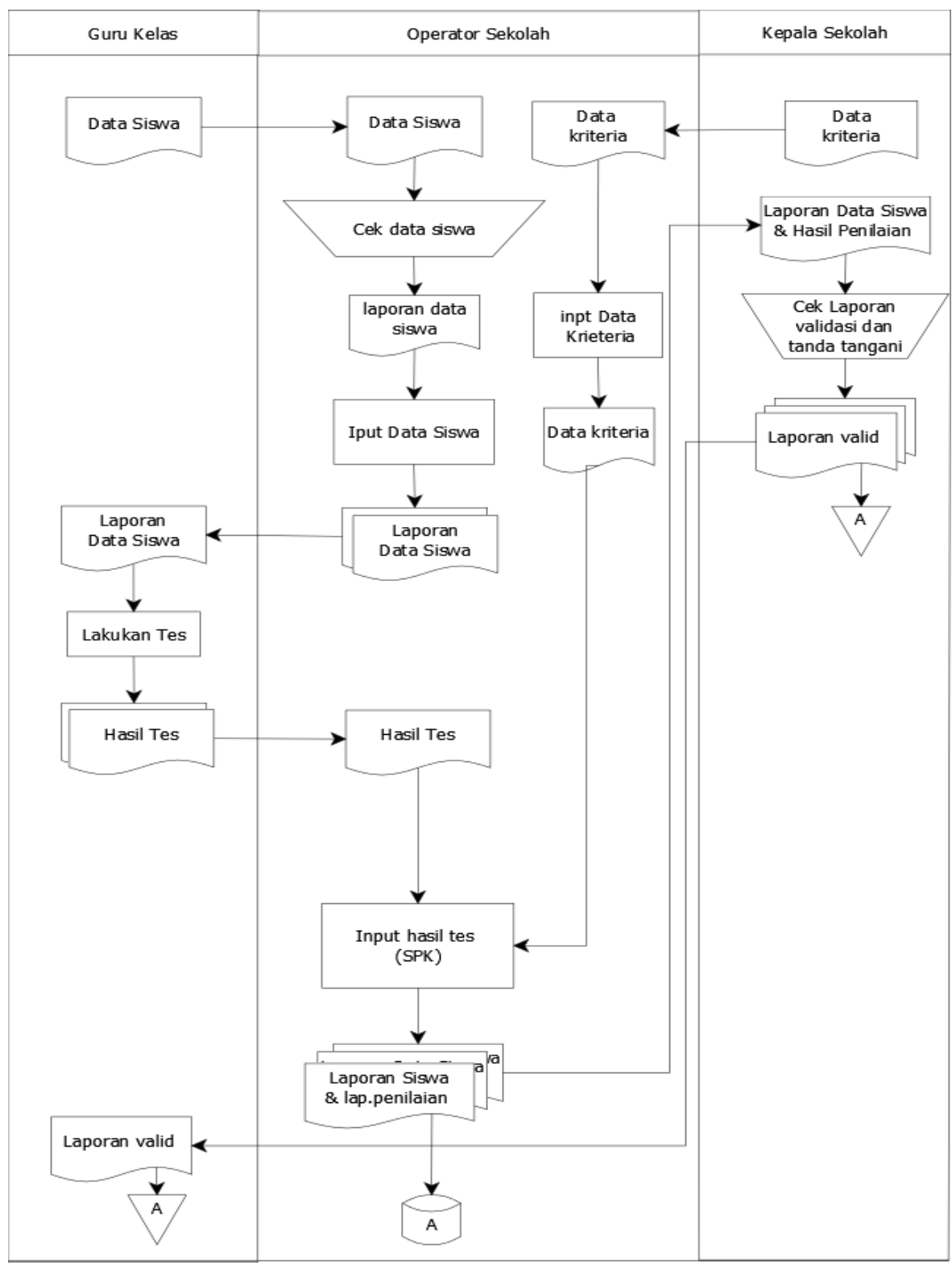

Gambar 3 : Aliran Sistem Informasi (ASI) yang baru

\subsection{Perancangan Sistem}

\section{a. Context Diagram}

Diagram konteks merupakan salah satu alat bantu dalam melakukan analisis terstruktur dan menganalisan sistem yang akan dikembangkan. Diagram konteks ini menggambarkan suatu sistem secara garis besarnya atau keseluruhannya saja. Dalam Diagram konteks juga digambarkan entitas eksternal yang merupakan perangkat pikir yang menghasilkan data yang akan diolah oleh sistem maupun tujuan dari informasi yang dihasilkan oleh sistem. Adapun diagram konteks yang diusulkan adalah sebagai berikut : 


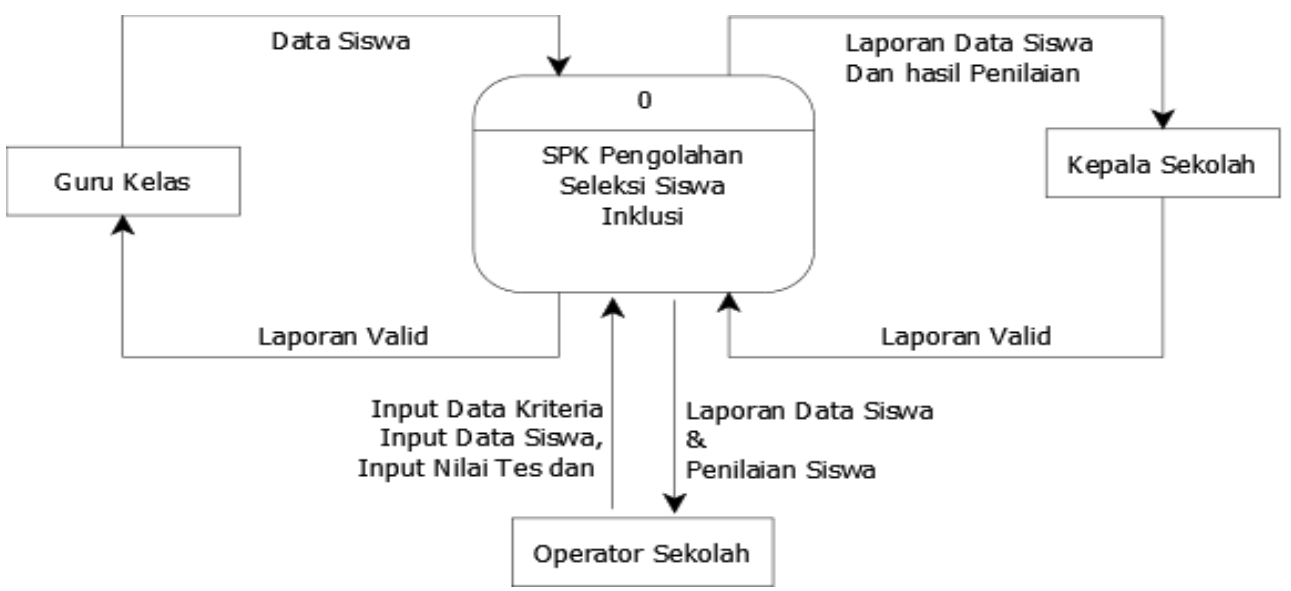

\section{Gambar 4. Context Diagram}

\section{b. Data Flow Diagram (DFD)}

DFD adalah gambaran sistem secara logika, gambaran ini tidak tergantung pada perangkat keras, perangka lunak, struktur data atau organisasi file. Keuntungan menggunakan DFD adalah untuk memudahkan pemakai yang kurang menguasai bidang komputer untuk mengerti sistem yang akan dikembangkan.

Untuk lebih rincinya dalam menggambarkan sistem pendukung keputusan (SPK) dan informasinya dapat dilihat pada gambar 5 berikut dibawah ini :

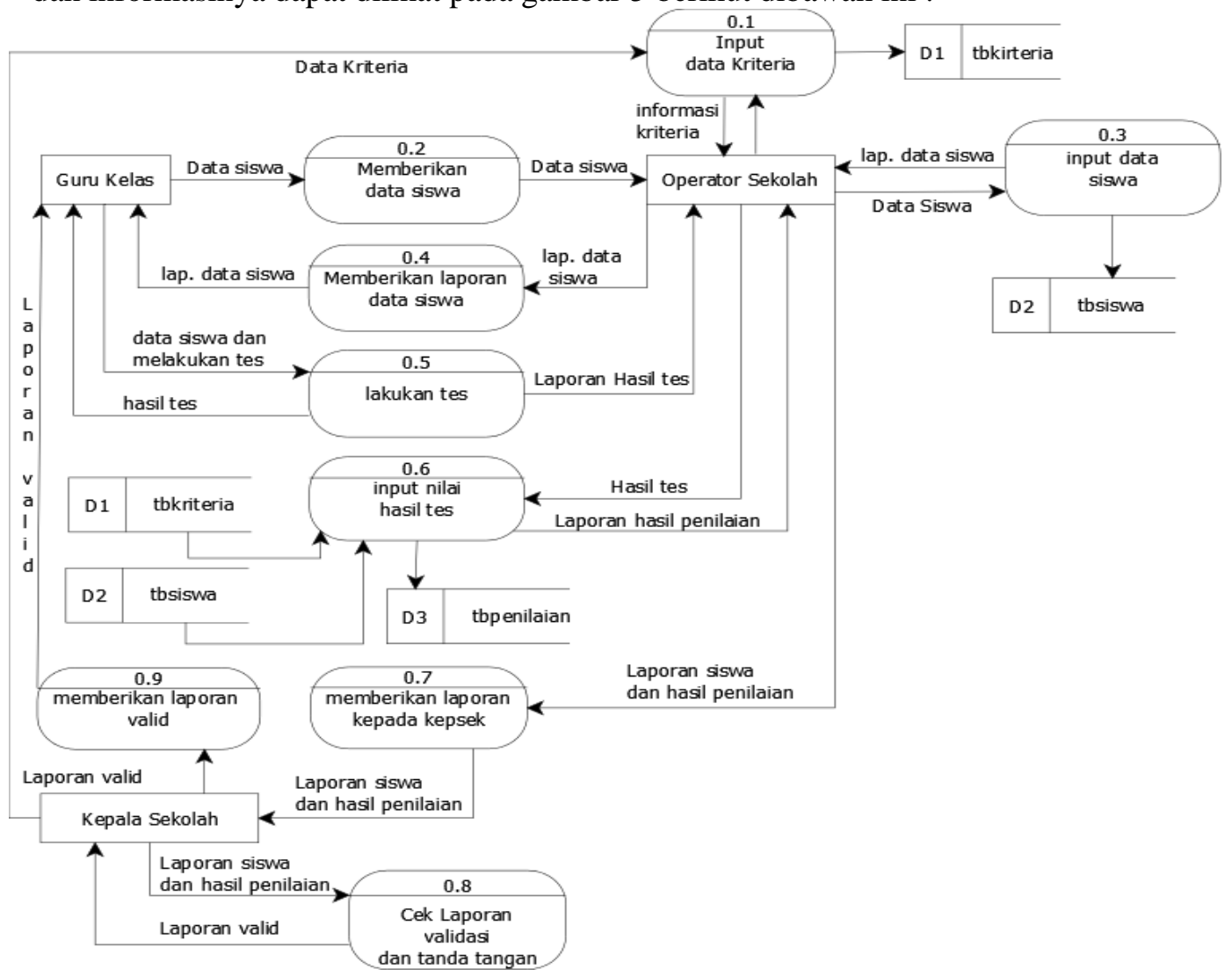

Gambar 5 Data Flow Diagram (DFD) 


\section{Implementasi Sistem}

a. Form Penilaian

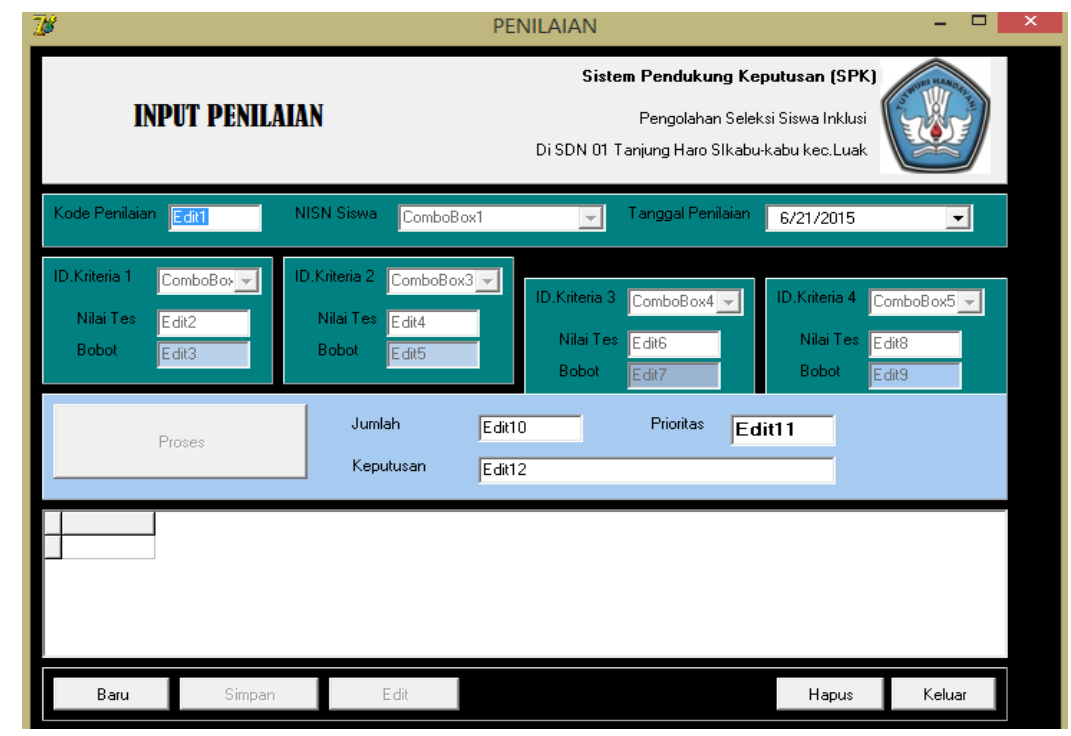

\section{Gambar 6. Form Penilaian}

Form penilaian pada gambar 6 di atas digunakan untuk menyeleksi calon siswa inklusi kesulitan belajar. Dimana masing-masing siswa sebelumnya telah menjalani serangkaian tes tertulis, seperti tes berhitung dan membaca, hasil penilaian tes tertulis kemudian diinputkan ke dalam form penilaian dan disesuaikan dengan bobot masingmasing kriteria yang telah ditetapkan. Keputusan penetapan siswa inklusi kesulitan belajar berdasarkan jumlah bobot dan nilai prioritas yang didapat masing-masing siswa dari penilaian tersebut. Semakin tinggi nilai prioritas, maka prioritas penetapan siswa inklusi tertuju pada siswa tersebut.

\section{Kesimpulan}

Sistem Penunjang keputusan penetapan siswa inklusi kesulitan belajar dapat digunakan untuk mempermudah pihak sekolah dalam menetapkan siswa kesulitan belajar sesuai kriteria yang telah ditetapkan dinas pendidikan. Sehingga dengan adanya sistem ini, penetapan siswa inklusi menjadi lebih objektif dan tepat sasaran, sehingga tujuan pemerintah dalam memberikan pendidikan untuk semua, termasuk siswa berkebutuhan khusus dapat terlaksana dengan baik. Sehingga siswa inklusi tersebut dapat terbantu kesulitan belajarnya dan lebih baik dalam proses belajar mengajar ke depannya.

\section{Daftar Pustaka}

[1] Undang Undang Dasar 1945 pasal 31 ayat 1 Tentang Hak Asasi Untuk Mendapat Pendidikan

[2] Undang-Undang Republik Indonesia Tentang Sistem Pendidikan Nasional Nomor 20 Tahun 2003

[3] Direktorat Pembinaan Sekolah Luar Biasa. 2006. Pengelompokan anak berkebutuhan khusus dan jenis pelayanannya. 
[4] Buana, W. (2015). Jurnal Edik Informatika Penerapan Fuzzy Mamdani Untuk Sistem Pendukung Keputusan Pemilihan Telepon Seluler Jurnal Edik Informatika. Edik Informatika.

[5] Edianto Berutu (2015), "Sistem pendukung Keputusan Pengangktan Karyawan Tetap Dengan Metode Analytical Hierarchy Process (AHP) pada PT. Perkebunan Lembah Bhakti Propinsi NAD Kab. Aceh Singkil, Jurnal Pelita Informatika Budi Darma, Volume : IX, Nomor : 3, ISSN : 2301-9425.

[6] Lestari, Novia dkk. (2017), "Implementasi Sistem Pendukung Keputusan Dalam Pemberian Bantuan Kepada Masyarakat Desa", Jurnal Sains dan Informatika, Vol. 3 Nomor : 12, E-ISSN : 2502-096x

[7] Mufizar, Teuku dkk. (2017), "Pemilihan Calon Penerima Bantuan Siswa Miskin Menggunakan Metode Analytical Hierarchy Process (AHP)", Citec Journal, Vol. 4 No. 1, ISSN: $2460-4259$

[8] Riyanto, E. (2016). Sistem Pendukung Keputusan Penerima Kartu Perlindungan Sosial (KPS) dengan Metode SAW ( Simple Additive Weighting ). Prosiding Seminar Nasional Ilmu Komputer (SNIK), 4-11.

[9] Rona Fitria (2012), "Proses Pembelajaran Dalam Setting Siswa Inklusi di Sekolah Dasar", Jurnal Ilmiah Pendidikan Khusus, Volume 1, Nomor 1

[10] Sari, R. E., Saleh, A., Utama, S. P., Kl, J. L., Sudarso, Y. O. S., Tanjung, K. M., \& Medan, M. (2014). Menggunakan Metode AHP ( Studi Kasus : Di STMIK Potensi Utama Medan ), 108-114. 